\title{
KORELASI ANTARA PERILAKU BERKELOMPOK DAN HASIL PRESENTASI PETA KONSEP SISWA DALAM PEMBELAJARAN KOOPERATIF BERBASIS MODUL ETNOSAINS SUBAK
}

\author{
Thalia Prasetya, Dewa Ayu Puspawati, Sang Putu Kaler Surata \\ Program Studi Pendidikan Biologi, Fakultas Keguruan dan Ilmu Pendidikan, \\ Universitas Mahasaraswati Denpasar
}

\begin{abstract}
Based on the observation that the information obtained in the junior Amarawati Tampaksiring is one of the schools that implement conventional learning models. To achieve the goal of education, conventional learning model is not very effective to implement. Therefore, innovation is required in learning. One way to do is to implement a module based cooperative learning etnoscience subak which emphasizes the aspects of group behavior and results presentation concept maps. The purpose of this study was to determine the effect of cooperative learning modules based on behavior etnoscience subak groups and the results of students' concept map presentation, as well as to determine the correlation between the behavior of the group and the results presentation concept maps. The experiment was conducted in the junior class VII B Amarawati Tampaksiring. Students were divided into six groups, and each group working on a concept map. Furthermore, observers provide an assessment with reference to the assessment rubric. From the data analysis, the results obtained flocking behavior scores increased from 273.5 to 497.5 with a significance level ( $p=0.028<0.05)$, which means learning a given effect on the behavior of groups of students. Increase also occurred in the results presentation concept maps where scores increased from 42.0 to 97.0 with a significance level ( $p=0.027<0.05)$, which shows the influence of learning the presentation of the results of students' concept maps. To test the correlation between the behavior of the group with the results presentation concept maps, correlation coefficient ( $\rho=0.986)$ indicating increasing students flocking behavior, the result presentation concept maps is increasing as well. Results significance level ( $p=0.000<0.05)$ showed that the flocking behavior correlates to the presentation of the results of students' concept maps. In conclusion, cooperative learning modules based etnoscience subak affect the increase in groups as well as the behavioral aspects of students' concept map presentation of results, and the two variables have a positive correlation in the study.
\end{abstract}

Key words : Mind map, Cooperative learning, Subak etnosains module

\section{PENDAHULUAN}

Berdasarkan hasil observasi diperoleh informasi bahwa di SMP
Amarawati Tampaksiring merupakan salah satu sekolah yang menerapkan model pembelajaran konvensional. Jika 
dilihat dari sudut pandang para ahli, pembelajaran konvensional kurang efektif karena peserta didik cenderung menjadi pasif (Setyawan, 2011). Melihat dari kelemahan tersebut, maka perlu dilakukan inovasi model pembelajaran yang akan mengembangkan tiga aspek penting dalam diri siswa. Salah satu model pembelajaran yang dapat diterapkan adalah pembelajaran kooperatif berbasis modul etnosains subak. Pemilihan subak sebagai media pembelajaran dalam modul didasari karena di kawasan SMP Amarawati Tampaksiring terdapat subak yang berpotensi sebagai sumber belajar, yaitu subak Pulagan.

Pembelajaran kooperatif berbasis modul etnosains subak menitikberatkan pada dua aspek penting, yaitu perilaku berkelompok peserta didik dan hasil presentasi peta konsep peserta didik. Perilaku kelompok dinilai sebagai aspek penting karena dengan belajar dalam kelompok, siswa cenderung mampu mengungkapkan pendapatnya tentang suatu hal. Aspek kedua adalah hasil presentasi peta konsep peserta didik. Variabel hasil presentasi peta konsep dipilih karena melalui peta konsep siswa akan terlatih untuk berdiskusi dalam kelompok. Keterkaitan antara variabel perilaku berkelompok dengan variabel hasil presentasi peta konsep sangat berperan bagi keberhasilan penyampaian materi pelajaran dan keberlanjutan pemahaman siswa terhadap materi.

Bertitik tolak dari latar belakang tersebut, penelitian ini bermaksud untuk mengetahui korelasi antara perilaku kelompok dan hasil persentasi peta konsep siswa dalam pembelajaran kooperatif berbasis modul etnosains subak di SMP Amarawati Tampaksiring".

\section{METODE PENELITIAN}

Penelitian ini dilaksanakan pada bulan Januari sampai bulan April tahun 2013, di kelas VII B SMP Amarawati Tampaksiring tahun ajaran 2012/2013. Sampel yang digunakan dalam penelitian ini berjumlah 39 orang. Desain penelitian yang digunakan dalam penelitian ini adalah Pre-Eksperimental dengan model One Group PretestPosttest Design. Rancangan penelitian ini menggunakan untuk satu kelompok, yaitu kelompok eksperimen. Data 
diambil dari sampel dengan dua tahapan, yaitu pretest dan posttest. Sebelum mengambil data, sampel dibagi menjadi enam kelompok. Setiap kelompok akan ditugaskan untuk membuat peta konsep dari tema pelajaran. Penilaian kedua variabdel diambil oleh observer dengan mengacu pada aspek-aspek yang ditentukan. Data diambil dengan menggunakan rubrik penilaian perilaku berkelompok (Surata, 2009) dan rubrik penilaian presentasi peta konsep (Hariyati, 2012). Rubrik perilaku kelompok dan rubrik presentasi peta konsep merupakan rubrik yang telah diuji dan digunakan dalam beberapa penelitian. Data pengamatan perilaku berkelompok dan hasil presentasi peta konsep dianalisis dengan menggunakan uji Wilcoxon Matched Pairs untuk menguji hipotesis komparatif dua sampel berpasangan bila data berbentuk ordinal (Sugiyono, 2011). Pengujian ini dilakukan untuk mengetahui peningkatan perilaku berkelompok dan hasil presentasi peta konsep. Sedangkan, untuk mengetahui adanya korelasi antara perilaku berkelompok terhadap hasil presentasi peta konsep, data dianalisis menggunakan uji Spearman RankCorrelation.

\section{HASIL DAN PEMBAHASAN}

\section{Hasil Penelitian}

\section{Analisis Perilaku Berkelompok}

Dalam penelitian perilaku kelompok memiliki empat aspek yang diamati, yaitu partisipasi kelompok (PK), pembagian tanggungjawab (PTB), kualitas interaksi (KI) dan peranan anggota dalam kelompok (PADK). Penilaian untuk perilaku kelompok dinilai langsung oleh observer. Penilaian untuk aspek perilaku kelompok dapat dilihat pada Tabel 1 
Tabel 1 Perbandingan Penilaian Perilaku Kelompok

\begin{tabular}{ccccccccccc}
\hline Kelompok & \multicolumn{9}{c}{ Pretest } & \multicolumn{3}{c}{ Posttest } \\
& PK & PTJ & KI & PADK & Jumlah & PK & PTJ & KI & PADK & Jumlah \\
\hline A & 10,5 & 12,0 & 10,5 & 11,5 & 44,5 & 20,5 & 19,0 & 23,5 & 20,0 & 83,0 \\
B & 13,5 & 12,0 & 13,0 & 12,0 & 50,5 & 23,5 & 23,0 & 22,0 & 21,5 & 90,0 \\
C & 12,0 & 12,0 & 14,0 & 14,0 & 52,0 & 24,5 & 23,0 & 21,0 & 27,0 & 95,5 \\
D & 11,0 & 11,5 & 9,5 & 11,5 & 43,5 & 19,0 & 21,0 & 19,0 & 22,0 & 81,0 \\
E & 10,0 & 11,0 & 10,0 & 11,0 & 42,0 & 19,5 & 21,0 & 18,0 & 17,0 & 75,5 \\
F & 9,5 & 10,5 & 9,0 & 12,0 & 41,0 & 18,0 & 20,5 & 17,0 & 17,0 & 72,5 \\
\hline Jumlah & 66,5 & 69,0 & 66,0 & 72,0 & 273,5 & 125,0 & 127,5 & 120,5 & 124,5 & 497,5 \\
\hline
\end{tabular}

Keterangan : Partisipasi Kelompok (PK), Pembagian Tanggungjawab (PTB), Kualitas interaksi (KI), Peranan Anggota dalam Kelompok (PADK).

Dari Tabel 1 terlihat bahwa jumlah skor dari keempat aspek perilaku berkelompok memiliki perbedaan rentang yang cukup jauh, yaitu dari 273,5 menjadi 497,5. Peningkatan skor tersebut semakin diperkuat setelah dilakukan uji Wilcoxon Matched Pairs dimana diperoleh $\left(Z_{6}=-2,201, \quad \mathrm{p}=0,028<0,05\right)$ yang menyatakan adanya perbedaan nyata antara pretest dan posttest. Hal ini berarti hipotesis 1 penelitian, yaitu pembelajaran kooperatif berbasis modul etnosains subak berpengaruh terhadap perilaku berkelompok dan hasil presentasi peta konsep siswa di SMP Amarawati Tampaksiring diterima.

Jika dilihat secara menyeluruh, kelompok $\mathrm{C}$ merupakan kelompok yang memperoleh skor tertinggi dari 52,0 menjadi 95,5, sedangkan skor terendah diperoleh kelompok $\mathrm{F}$ dari 41,0 menjadi 72,5. Sedangkan, jika ditinjau dari aspek pengamatan dapat dilihat bahwa semua aspek mengalami peningkatan. Aspek PTJ merupakan aspek yang memiliki skor tertinggi, yaitu dari 69,0 menjadi 127,5 dan aspek KI menjadi aspek yang memperoleh skor terendah, yaitu dari 66,0 menjadi 120,5 .

\section{Analisis Hasil Presentasi Peta Konsep}

Berdasarkan analisis data yang dilakukan, hasil presentasi peta konsep siswa menunjukkan peningkatan yang signifikan dan terjadi di semua aspek yang diamati. Perbandingan hasil presentasi peta konsep siswa dapat dilihat pada Tabel 2

Tabel 2 Perbandingan Penilaian Hasil Presentasi Peta Konsep. 


\begin{tabular}{ccccccccccccc}
\hline Kelompok & \multicolumn{3}{c}{ Pretest } & \multicolumn{1}{c}{ Posttest } \\
& A1 & A2 & A3 & A4 & A5 & Jumlah & A1 & A2 & A3 & A4 & A5 & Jumlah \\
\hline A & 2,0 & 1,5 & 1,0 & 1,0 & 1,0 & 6,5 & 3,0 & 3,0 & 3,0 & 3,5 & 3,5 & 16,0 \\
B & 2,0 & 1,0 & 1,0 & 2,0 & 2,0 & 8,0 & 4,0 & 3,0 & 3,0 & 4,0 & 4,0 & 18,0 \\
C & 2,0 & 1,5 & 1,5 & 2,0 & 2,0 & 9,0 & 4,0 & 4,0 & 3,5 & 4,0 & 4,0 & 19,5 \\
D & 2,0 & 1,0 & 1,0 & 1,0 & 2,0 & 7,0 & 3,0 & 3,0 & 3,0 & 3,0 & 3,5 & 15,5 \\
E & 1,0 & 1,0 & 1,0 & 2,0 & 1,0 & 6,0 & 3,0 & 3,0 & 3,0 & 2,0 & 3,5 & 14,5 \\
F & 1,0 & 1,0 & 1,5 & 1,0 & 1,0 & 5,5 & 2,0 & 3,0 & 2,5 & 3,0 & 3,0 & 13,5 \\
\hline Jumlah & 10,0 & 7,0 & 7,0 & 9,0 & 9,0 & 42,0 & 19,0 & 19,0 & 18,0 & 19,5 & 21,5 & 97,0 \\
\hline
\end{tabular}

Keterangan : Keterkaitan antara Isi Peta Konsep dengan Pokok Bahasan yang Dijelaskan (A1), Kerapian Pembuatan Peta Konsep (A2), Warna, Tulisan dan Garis Desain Peta Konsep yang Menarik (A3), Penguasaan Peta Konsep oleh Masing-Masing Anggota Kelompok (A4) serta Kemampuan Menjawab Pertanyaan (A5).

Tabel 2 menunjukkan bahwa antara skor pretest dan posttest mengalami peningkatan dari 42,0 menjadi 97,0. Dilihat dari kelompok, terlihat kelompok $\mathrm{C}$ adalah kelompok yang memiliki skor tertinggi, yaitu dari 9,0 menjadi 19,5 dan kelompok $F$ memperoleh skor terendah, yaitu dari 5,5 menjadi 13,5. Sedangkan, jika ditinjau dari aspek penilaian terlihat bahwa aspek kemampuan menjawab pertanyaan (A5) memperoleh skor tertinggi pada saat posttest, yaitu 21,5 dan aspek dengan skor terendah terlihat pada aspek warna, tulisan, dan garis desain peta konsep yang menarik (A3), yaitu 18,0. Hasil tersebut diperkuat oleh hasil uji Wilcoxon Matched Pairs dimana diperoleh $\quad\left(Z_{6}=-2,207\right.$, $\mathrm{p}=0,027<0,05) \quad$ yang menunjukkan bahwa terdapat perbedaan nyata antara pretest dan posttest Hasil tersebut membuktikan hipotesis pertama penelitian, yaitu pembelajaran kooperatif berbasis modul etnosains subak berpengaruh terhadap perilaku berkelompok dan hasil presentasi peta konsep siswa di SMP Amarawati Tampaksiring diterima.

\section{Korelasi antara Perilaku Kelompok} dengan Hasil Presentasi Peta Konsep

Langkah awal yang dilakukan guna mengetahui hubungan kedua variabel adalah mencari selisih data antara sebelum dan sesudah pembelajaran. Berdasarkan skor selisih terlihat kelompok $\mathrm{C}$ mendominasi dengan perolehan skor tertinggi, yaitu perilaku berkelompok dengan skor 43,5 
dan hasil presentasi peta konsep dengan skor 10,5. Kelompok F menjadi kelompok yang memperoleh skor terendah dengan skor 31,5 untuk perilaku berkelompok dan skor 8,0 untuk hasil presentasi peta konsep. Peningkatan perilaku berkelompok yang sejalan dengan peningkatan hasil presentasi peta konsep dapat dilihat pada Gambar 1.

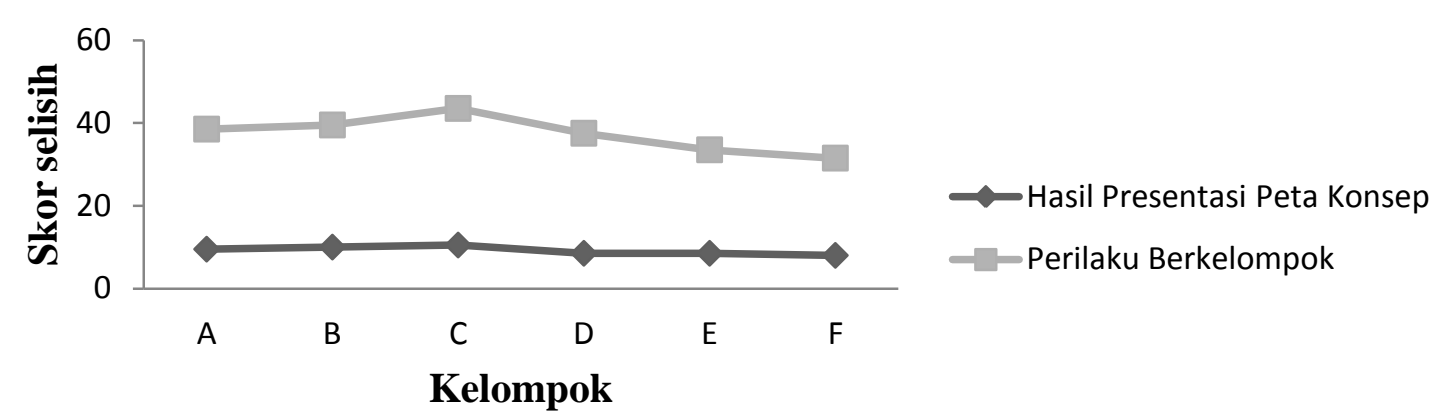

Gambar 1 Korelasi antara Perilaku Berkelompok dengan Hasil Presentasi Peta Konsep Siswa Ditinjau dari Kelompok

Dari Gambar 1 terlihat antara variabel perilaku berkelompok dengan hasil presentasi peta konsep memiliki hubungan positif. Semakin meningkat perilaku berkelompok, maka hasil presentasi peta konsep semakin meningkat pula. Temuan tersebut semakin diperkuat dengan hasil uji Spearman Rank-Correlation dimana diperoleh koefisien korelasi $(\rho=0,986)$ dengan taraf signifikansi yang lebih kecil dari probabilitas $(\mathrm{p}=0,000)$, maka dapat disimpulkan bahwa hipotesis kedua, yaitu terdapat korelasi antara perilaku berkelompok siswa dalam pembelajaran kooperatif berbasis modul etnosains subak terhadap hasil presentasi peta konsep siswa diterima.

\section{Pembahasan}

\section{Perilaku Berkelompok}

Berdasarkan pengamatan dan analisis data yang telah dilakukan diperoleh peningkatan skor perilaku berkelompok dari 273,5 menjadi 497,5 dengan taraf signifikansi $(\mathrm{p}=0,028<0,05)$ yang berarti terdapat perbedaan nyata antara sebelum dan sesudah kegiatan pembelajaran. Hasil tersebut sekaligus menyimpulkan bahwa 
pembelajaran kooperatif berbasis modul etnosains subak berpengaruh terhadap perilaku berkelompok siswa di SMP Amarawati Tampaksiring. Keberhasilan tersebut dikarenakan pembelajaran kooperatif berbasis modul etnosains subak memberikan kesempatan bagi siswa untuk bertukar pikiran dengan teman sebaya, memberikan ruang interaksi bagi siswa serta membukakan peluang komunikasi antar siswa. Pendapat tersebut juga disampaikan oleh siswa dalam kegiatan diskusi kelompok terarah (DKT). Menurut mereka belajar dalam kelompok memiliki beberapa keunggulan dibanding belajar secara individu, antara lain :

“...Belajar secara berkelompok memberikan kesempatan untuk bertukar pikiran, saling bertanya mengenai materi pelajaran tanpa ada rasa takut, memecahkan persoalan pelajaran menjadi lebih mudah dan dengan dibentuk kelompok kami menjadi lebih akrab".

Nilai positif dari pembelajaran kooperatif didukung juga oleh hasil penelitian dari Subratha (2006) yang menemukan bahwa dengan penerapan pembelajaran kooperatif kualitas interaksi siswa menjadi semakin meningkat, yaitu dari rata-rata nilai 73,47 menjadi 78,31. Peningkatan dapat tercapai secara optimal dikarenakan siswa ditempatkan kelompok belajar yang memungkinkan siswa untuk saling melengkapi dalam memahami materi pembelajaran. Temuan tersebut juga didukung oleh hasil penelitian Supriono (2008) dimana dari hasil wawancara dengan siswa diketahui :

“...Melalui penerapan pembelajaran kooperatif sikap positif siswa dapat meningkat, seperti membantu teman memahami materi dan saling memberikan dorongan untuk belajar".

Pembelajaran dengan berbasis modul etnosains subak juga menjadi sebuah sarana pembelajaran lingkungan bagi siswa. Siswa menjadi lebih paham tentang subak serta kehidupan yang terjadi di subak dan mengetahui peran penting subak bagi kehidupan. Pengetahuan tersebut dijadikan sebagai sebuah alasan untuk ikut melestarikan keberadaan subak. Pendapat mengenai hal tersebut didukung oleh hasil penelitian yang dilakukan Sudiana \& Maduriana (2008) yang menemukan bahwa $90 \%$ responden berpendapat jika 
pendidikan lingkungan dengan menggunakan subak sebagai model dapat meningkatkan upaya pelestarian Bali. Selain itu, menurut pendapat salah satu responden yang berprofesi sebagai guru :

“...Menggunakan subak sebagai model maka anak didik akan mengenal lebih mendalam salah satu warisan budaya nasional, menumbuhkan kecintaan terhadap lingkungan dan menciptakan lapangan pekerjaan".

Penekanan perilaku berkelompok dalam pembelajaran merupakan salah satu langkah yang penting. Menempatkan siswa dalam kelompok secara tidak langsung mengembangkan jiwa sosial siswa. Penilaian perilaku berkelompok menitikberatkan pada 4 aspek, yaitu partisipasi kelompok (PK), pembagian tanggung jawab (PTJ), kualitas interaksi (KI) dan peranan anggota dalam kelompok (PADK). Melalui keempat aspek tersebut siswa akan belajar tentang cara menempatkan diri dalam kehidupan sosial. Pembelajaran kooperatif berbasis modul etnosains subak ternyata mampu membelajarkan siswa untuk bekerja sama, terlihat dari perolehan skor aspek pembagian tanggung jawab yang tinggi.
Dari skor tersebut dapat disimpulkan bahwa dalam mengerjakan tugas yang diberikan setiap kelompok sudah mampu mempercayai anggotanya untuk menyelesaikan suatu tugas. Sedangkan, aspek kualitas interaksi masih menjadi kendala tersendiri bagi siswa. Kualitas interaksi yang kurang dapat dikarenakan konsentrasi dan kesibukan siswa untuk fokus menyelesaikan tanggung jawab yang diberikan. Terlepas dari permasalahan tersebut yang perlu ditekankan bahwa semua aspek perilaku berkelompok siswa mengalami peningkatan yang signifikan. Peningkatan tersebut juga memberikan gambaran bahwa pembelajaran kooperatif berbasis modul etnosains subak mampu membentuk perilaku berkelompok siswa dari berbagai aspek sosial.

\section{Hasil Presentasi Peta Konsep}

Berdasarkan hasil uji statistik yang dilakukan didapatkan peningkatan skor hasil presentasi peta konsep dari 42,0 menjadi 97,0 dengan taraf signifikansi $(\mathrm{p}=0,027<0,05)$. Hasil tersebut menunjukkan bahwa penerapan pembelajaran kooperatif berbasis modul 
etnosains subak berpengaruh terhadap hasil presentasi peta konsep siswa. Keberhasilan tersebut bukan sebuah hal yang mudah, dalam faktanya terdapat kendala yang ditemukan di lapangan antara lain : siswa belum terbiasa dengan model pembelajaran yang diberikan, siswa masih merasa malu untuk bertanya dan siswa merasa kesulitan untuk memahami tentang peta konsep. Kendala-kendala tersebut menjadi sebuah refleksi untuk mendapatkan hasil yang maksimal. Dalam penerapannya, peneliti berusaha menjelaskan kepada siswa tentang konsep pembelajaran kooperatif berbasis modul etnosains subak secara detail serta memberikan contoh-contoh sederhana peta konsep kepada siswa. Selanjutnya, siswa secara sendiri mampu memahami mengenai proses pembelajaran yang dijalani. Terbukti dari hasil presentasi peta konsep siswa antara pretest dan posttest mengalami peningkatan yang signifikan.

Dari hasil wawancara dengan siswa dalam kegiatan DKT diketahui bahwa untuk menghasilkan peta konsep yang baik, mereka mengacu pada modul etnosains subak yang diberikan. Materi yang singkat dan jelas memudahkan mereka memahami materi pelajaran dan menemukan pokok pikiran dari setiap subbab materi. Modul etnosains subak juga memiliki beberapa nilai positif bagi siswa, antara lain :

"...Belajar dengan menggunakan modul etnosains subak menjadikan proses belajar lebih mudah karena semua materi pembelajaran sudah tercantum dengan lengkap, penggunaan gambar membuat modul lebih menarik minat belajar dibandingkan lembar kerja siswa, dan belajar dengan modul membuat semua konsep pelajaran dapat diingat".

Pendapat tersebut juga didukung hasil penelitian Wibowo (2012) yang menemukan bahwa pembelajaran dengan menggunakan modul meningkatkan keterampilan proses sains siswa. Hal tersebut dibuktikan dengan perolehan rata-rata nilai siswa sebesar 85. Pencapaian rata-rata nilai 85 dikarenakan pada saat pembelajaran siswa lebih merasa antusias menemukan konsep-konsep pelajaran dengan menggunakan modul. Kesuksesan siswa dalam mencapai hasil presentasi peta konsep dengan media modul sekaligus mematahkan hasil penelitian Ceisar (2012) yang menemukan bahwa 
pembelajaran dengan modul ilustratif memberikan kendala bagi siswa untuk meningkatkan prestasi belajar.

Penugasan setiap kelompok untuk membuat peta konsep dimaksudkan untuk memacu siswa dalam menyelesaikan tugas secara maksimal, membantu siswa dalam mengingat materi serta melatih siswa untuk belajar secara mandiri. Jika ditinjau dari kelima aspek penilaian, maka aspek kemampuan menjawab pertanyaan memperoleh skor tertinggi, yaitu 21,5. Menempatkan kelompok belajar menjadikan siswa aktif berperan serta dalam menyelesaikan peta konsep yang ditugaskan, sehingga saat kegiatan presentasi dan diskusi setiap anggota kelompok dapat menjawab pertanyaan yang diberikan. Hasil yang diperoleh juga didukung oleh penelitian Susilawati (2008) yang menemukan bahwa peningkatan hasil belajar siswa pada siklus II dikarenakan penggunaan strategi peta konsep dalam proses belajar mengajar dapat meningkatkan kualitas proses pembelajaran, meliputi penurunan tingkat miskonsepsi, peningkatan peran serta siswa serta peningkatan peran dan ketrampilan siswa dalam presentasi kelas. Untuk skor terendah dapat dilihat pada aspek warna, tulisan dan garis desain peta konsep yang menarik, yaitu 18. Faktor yang menyebabkan skor aspek tersebut rendah adalah pengaturan waktu yang kurang tepat, sehingga membuat pola garis, penulisan materi pembelajaran dan pemilihan warna menjadi kurang rapi.

Meskipun demikian, terlihat data setiap kelompok di semua aspek penilaian mengalami peningkatan karena belajar dengan menggunakan peta konsep lebih memudahkan siswa menyelesaikan tugas yang diberikan.

\section{Korelasi Perilaku Berkelompok dengan Hasil Presentasi Peta Konsep}

Dari hasil uji statistik diperoleh hasil koefisien korelasi $(\rho=0,986)$ yang menunjukkan bahwa antara perilaku berkelompok dengan hasil presentasi peta konsep memiliki hubungan yang positif, yaitu semakin meningkat perilaku berkelompok, maka hasil presentasi peta konsep juga meningkat. Berdasarkan nilai taraf signifikansi $(\mathrm{p}=0,000<0,05)$, maka dapat disimpulkan terdapat korelasi antara 
perilaku berkelompok dalam pembelajaran kooperatif berbasis modul etnosains subak terhadap hasil presentasi peta konsep siswa. Keeratan hubungan kedua variabel terjadi karena dalam mengerjakan tugas pembuatan peta konsep, setiap anggota kelompok diberikan kesempatan untuk berpendapat tentang pokok pelajaran yang akan dicantumkan dalam peta konsep, sehingga hasil peta konsep menjadi kompleks dan relevan dengan tema pembelajaran. Hubungan antara variabel perilaku berkelompok dan hasil presentasi peta konsep juga terlihat ketika siswa mempresentasikan hasil peta konsep yang dibuat. Setiap anggota kelompok terlihat sangat antusias dalam menyajikan peta konsep dan pada saat diskusi, setiap anggota kelompok saling berkomunikasi untuk menjawab pertanyaan yang diberikan. Mengacu pada hasil DKT, siswa merasakan manfaat dari belajar kelompok dalam membuat peta konsep, antara lain :

“...Membuat peta konsep dengan berkelompok memudahkan pemahaman materi, dapat bertanya pada teman sebaya dan pemecahan soal-soal pelajaran menjadi lebih maksimal daripada belajar individu".

\begin{abstract}
Keberhasilan setiap kelompok dalam mempresentasikan hasil peta konsep tidak terlepas dari kerja sama yang dibangun. Pendapat tersebut didukung oleh hasil penelitian Gunawan (2010) yang menemukan bahwa dengan adanya kerjasama, rasa saling ketergantungan positif serta keinginan untuk menyamakan presepsi dan pemahaman terhadap pengetahuan, maka masing-masing anggota akan berusaha optimal untuk mengkontribusikan pengetahuan serta menjalankan tugas sebaik-baiknya, sehingga tujuan kelompok akan tercapai secara utuh. Hasil tersebut dibuktikan dengan perolehan hasil uji statistik yaitu $\mathrm{P} \leq 0,05$ yang berarti terdapat perbedaan nyata antara sebelum dan sesudah pembelajaran. Pentingnya kerjasama dalam kelompok juga diungkapkan oleh Mulyaningrum (2012) dalam hasil penelitiannya yang menemukan bahwa kerjasama yang terjalin baik akan menjadikan siswa bersaing secara positif, khususnya dalam mencapai prestasi terbaik.

Jika dilihat dari aspek pengamatan perilaku berkelompok, aspek pembagian
\end{abstract}


tanggung jawab merupakan faktor utama yang menyebabkan hasil presentasi peta konsep maksimal, khususnya dalam aspek menjawab pertanyaan. Memberikan tanggung jawab individu dalam kelompok belajar ternyata memacu siswa untuk melakukan yang terbaik, hal tersebut terlihat dari kemampuan siswa menjawab semua pertanyaan yang diberikan, baik pada saat diskusi ataupun presentasi. Inilah yang menyebabkan skor kemampuan menjawab pertanyaan memperoleh skor tertinggi dari kelima aspek hasil presentasi peta konsep.

Jika ditinjau dari kelompok diketahui bahwa semua kelompok berhasil menyelesaikan tugas peta konsep dengan baik. Kelompok A dapat memperoleh skor 9,5 untuk hasil presentasi peta konsep karena kualitas interaksi antar anggota kelompok sangat maksimal dibandingkan kelompok lain. Sedangkan keberhasilan kelompok B memperoleh skor 10,0 untuk hasil presentasi peta konsep dikarenakan setiap anggota kelompok sudah berpartisipasi meskipun kualitas interaksi yang terjadi belum maksimal.
Kelompok C menjadi kelompok yang memperoleh skor tertinggi, yaitu 10,5 untuk hasil presentasi peta konsep. Tingginya skor kelompok C dikarenakan setiap anggota sudah mampu menjalankan peranannya di dalam kelompok secara maksimal, sehingga tugas yang diberikan dapat terselesaikan dengan hasil terbaik. Anggota kelompok D juga sudah menjalankan peranannya secara maksimal, tetapi kualitas interaksi dan partisipasi kelompok yang terjalin belum maksimal, sehingga kelompok D dapat memperoleh skor hasil presentasi peta konsep cukup baik, yaitu 8,5. Skor selisih 8,5 juga diperoleh kelompok E, skor tersebut dapat diperoleh karena pembagian tanggung jawab antar anggota kelompok sudah merata . Sedangkan, skor terendah diperoleh kelompok F, yaitu 8,0 untuk hasil presentasi peta konsep. Rendahnya skor yang diperoleh diakibatkan dari kurang maksimalnya peranan dari masingmasing anggota kelompok untuk menjalankan tanggung jawab yang diberikan. Terlepas dari hal tersebut dapat disimpulkan bahwa menerapkan kelompok belajar memberikan peranan 
yang besar dalam peningkatan hasil presentasi peta konsep.

\section{PENUTUP}

\section{Simpulan}

Adapun kesimpulan dari hasil penelitian yang telah dilakukan, yaitu :

1) Pembelajaran kooperatif berbasis modul etnosains subak berpengaruh nyata $(\mathrm{p}=0,028<0,05)$ terhadap perilaku berkelompok dan $\quad(p=0,027<0,05)$ terhadap hasil presentasi peta konsep siswa di SMP Amarawati Tampaksiring; 2) Perilaku berkelompok berkorelasi $(\mathrm{p}=0,000<0,05) \quad$ terhadap hasil presentasi peta konsep siswa dalam pembelajaran kooperatif berbasis modul etnosains subak.

\section{Saran}

Berdasarkan temuan-temuan dalam penelitian ini, maka saran yang dapat disampaikan antara lain sebagai berikut : 1) Diharapkan kepada siswa untuk lebih berperan aktif dalam proses pembelajaran, sehingga tujuan pembelajaran dapat tercapai secara maksimal; 2) Diharapkan kepada guru untuk menerapkan pembelajaran kooperatif berbasis modul etnosains subak untuk memaksimalkan pencapaian tujuan pembelajaran dan mengembangkan aspek perilaku berkelompok serta hasil presentasi peta konsep; 3) Diharapkan kepada sekolah untuk menjadikan pembelajaran kooperatif berbasis modul etnosains subak sebagai acuan dalam membuat kebijakan penerapan model pembelajaran yang inovatif; 4) Diharapkan kepada peneliti untuk menjadikan pembelajaran kooperatif berbasis modul etnosains subak sebagai salah satu tolak ukur dalam melakukan penelitian terkait inovasi pembelajaran berbasis lingkungan.

\section{DAFTAR PUSTAKA}

Ceisar, M, A.A. (2011). Pembelajaran biologi menggunakan inkuiri terbimbing melalui media animasi dan modul ilustratif. Paper dipublikasikan pada Jurnal Prosiding Seminar Nasional Biologi Vol 8, No 1, Tahun 2011. Diunduh pada tanggal 13 Februari 2013 dari http://

http://jurnal.fkip.uns.ac.id/.

Gunawan, A. I W. (2010). Pembelajaran kooperatif kelompok investigasi dengan pendekatan digital artistik untuk meningkatkan ketrampilan berkelompok mahasiswa pada pembelajaran 
ekoliterasi ketahanan hayati program studi biologi Universitas Mahasaraswati Denpasar tahun akademik 2008/2009. Paper dipublikasikan pada Jurnal Santiaji Pendidikan Universitas Mahasaraswati Denpasar, Volume 1 , No.2 tahun 2011.

Hariyati, J. I K. (2012). Pengaruh penerapan metode pembelajaran kooperatif STAD (student teams achievement divisions) melalui peta konsep terhadap hasil belajar biologi siswa semester genap SMA Negeri 1 Petang tahun pelajaran 2011/2012 (Skripsi Tidak Dipublikasikan). Universitas Mahasaraswati, Denpasar.

Setyawan, H. (2011). Pengertian, kelebihan dan kekurangan metode ceramah. Diunduh pada tanggal 06 Februari 2013 dari http://zonainfosemua.blogspot.c om.

Subratha, N. (2006). Pengembangan model pembelajaran kooperatif dan strategi pemecahan masalah untuk meningkatkan hasil belajar siswa kelas VII C SMP Negeri 1 Sukasada. Paper dipublikasikan pada Jurnal Penelitian dan Pengembangan Lembaga Penelitian Undiksha tahun 2007. Diunduh pada tanggal 28 Juni 2013 dari www.freewebs.com.

Sudiana, I M \& Maduriana, I M. (2008). Sikap guru terhadap pengembangan subak sebagai model pendidikan lingkungan (penelitian pada guru sekolah menengah tingkat atas di kabupaten Tabanan). Paper dipublikasikan pada Indonesian Scientific Journal Database Vol 41. Diunduh pada tanal 12 Februari 2013 dari http:// isjd.pdii.lipi.go.id/.

Sugiyono. (2011). Metode penelitian pendidikan pendekatan kuantitatif, kualitatif, dan $R \& D$. Bandung : Alfabeta. Cetakan ke1.

Supriono. (2008). Penerapan model pembelajaran kooperatif peta konsep untuk meningkatkan motivasi dan hasil belajar siswa. Paper dipublikasikan pada Jurnal Pendidikan Inovatif Volume 3, No.2 tahun 2008. Diunduh pada tanggal 28 April 2013 dari http://jurnaljpi.files.wordpress.co $\mathrm{m}$

Surata, S. P. K. (2009). Rubrik pengamatan perilaku berkelompok (Rubrik Tidak Dipublikasikan). Universitas Mahasaraswati, Denpasar.

Susilawati, D, F. (2008). Implementasi strategi peta konsep dalam cooperatif learning sebagai upaya meminimalisasi miskonsepsi bioteknologi di SMA Negeri 8 Surakarta. Paper dipublikasikan pada Jurnal Pembelajaran Biologi Universitas Sebelas Maret Surakarta. Diunduh pada tanggal 13 Februari 2013 dari http:// http://jurnal.fkip.uns.ac.id/ 
Wibowo, H, P. (2012). Pengaruh penggunaan modul hasil penelitian bentos pada pokok bahasan pencemaran lingkungan terhadap keterampilan proses sains siswa kelas X Sma Negeri 1 Mojolaban tahun pelajaran 2011/2012. Dipublikasikan pada Jurnal Pembelajaran Biologi Universitas Sebelas Maret Surakarta. Diunduh pada tanggal 13 Februari 2013 dari http://jurnal.fkip.uns.ac.id/. 